\begin{tabular}{|c|c|c|}
\hline $\begin{array}{l}\text { PKS } \\
\text { PUBLIC } \\
\text { KNOWEDGE } \\
\text { PROJECT }\end{array}$ & $\begin{array}{c}\text { REVISTA DE GEOGRAFIA } \\
\text { (RECIFE) } \\
\text { http://www.revista.ufpe.br/revistageografia }\end{array}$ & $\begin{array}{l}\text { OJS } \\
\frac{\text { OPEN }}{\text { OPUNAL }} \\
\text { SYSTEMS }\end{array}$ \\
\hline
\end{tabular}

\title{
CLIMATE CLASSIFICATION IN KÖPPEN MODEL FOR THE STATE OF PERNAMBUCO - BRAZIL
}

\author{
Raimundo Mainar de Medeiros ${ }^{1}$, Romildo Morant de Holanda ${ }^{2}$, Mirella Alexandre \\ Viana $^{3}$, Vicente de Paulo Silva ${ }^{4}$
}

\begin{abstract}
${ }^{1}$ Dr. em Meteorolgia e Pesquisador na Universidade Federal Rural de Pernambuco. E-mail: mainarmedeiros@gmail.com

${ }^{2}$ Professor Doutor na Universidade Federal Rural de Pernambuco. E-mail: romildomorant@gmail.com

${ }^{3}$ Professor Doutor na Universidade Federal Rural de Pernambuco. E-mail: vicenteufrpe@yahoo.com.br

4 Discente do Programa de Pós-graduação em Engenharia Ambiental na Universidade Federal Rural de Pernambuco.
\end{abstract}

Artigo recebido em 26/06/2017e aceito em 21/11/2017

\begin{abstract}
The Köppen climate classification system is little used in agricultural studies because of the large extent of the planting scales in which they are used. It was used the series of historical rainfalls observed in 187 municipalities of the state of Pernambuco - Brazil. For the spatialization of the results, the Kriging interpolation method was used. The indicated classifications showed to be very sensitive to the municipal orography, to the pluviometric indices and to the temperature variations resulting in three climatic types according to the Köppen model. According to Köppen classification systems, three climatic characteristics were identified: AS type in 108 municipalities, the semi-arid hot type with summer and dry winter precipitation (BSH) was recorded in 55 municipalities and type Am predominated in 20 municipalities. The climatic classification according to Köppen for the studied area is in agreement with the classifications of Camargo (1961). The Kriging model adapted the results satisfactorily in the geospatial data obtained for the state of Pernambuco. The Köppen climate classification system is efficient only for the macro-scale and with low capacity for separating climate types, taking into account air temperature, rainfall and elements resulting from the water balance.
\end{abstract}

Keywords: thermal and rainfall fluctuations; Kriging model; climatic types.

\section{CLASSIFICAÇÃO CLIMÁTICA NO MODELO KÖPPEN PARA O ESTADO DE PERNAMBUCO - BRASIL}

\section{RESUMO}

O sistema de classificação climática Köppen é pouco utilizado nos estudos agrícolas devido à grande extensão das escalas de plantio em que são utilizadas. Foi utilizada a série de chuvas históricas observadas em 187 municípios do estado de Pernambuco. Para a espacialização dos resultados, utilizou-se o método de interpolação Kriging. As classificações indicadas mostraram-se muito sensíveis à orografia municipal, aos índices pluviométricos e às variações de temperatura resultando em três tipos climáticos de acordo com o modelo de Köppen. De acordo com os sistemas de classificação de Köppen, foram identificadas três características climáticas: do tipo AS em 108 municípios, o tipo semiárido quente com precipitação de verão e inverno seco (BSH), foi registrado em 55 municípios e o tipo Am predominou em 20 municípios. A classificação climática de acordo com Köppen para a área estudada está de acordo com as classificações de Camargo (1961). O modelo Kriging adaptou os resultados de forma satisfatória nos dados geoespaciais obtidos para o estado de Pernambuco. O sistema de classificação climática Köppen é eficiente apenas para a macro-escala e com baixa capacidade para separar os tipos de clima, levando em consideração a temperatura do ar, as chuvas e os elementos resultantes do balanço hídrico.

Palavras-chave: flutuações térmicas e pluviométricas; modelo Kriging; tipos climáticos. 


\section{INTRODUCTION}

Costa et al. (2011) showed that the energy contained in the mediumdue to air temperature, propagates in a simple way. In the course of a day, the energy that is available to the environment oscillates between two extreme values the minimum and the maximum. As this energy goes from one end to the other, it acts in the continuous stimulation of vital physiological processes in living beings, such as the development and growth of plant species, like: perspiration, respiration, germination, growth, flowering and fruiting. At different plant development stages, there are adequate ranges of temperatures for their perfect development.

Many researchers have used the Köppen's climate classification as a basis for studies in agroclimatic zoning in Brazil (JURCA, 2005; ROLIM et al., 2007) and Mexico (MAES et al., 2009), in assisting the zonings of forestry species (ARAÚJO et al., 2012) and Eucalyptus grandis rust occurrence (SILVA et al., 2013), and also in climatic zoning of Eucalyptus plantations across Brazil (GONÇALVES et al., 2013).

Other studies used the Ko"ppen system in meteorology (GNANDESIKAN et al., 2006) and hydrology (MCMAHON et al., 2007). Recently, significant contributions have been published to the climate change issue (FRAEDRICH et al, 2001; KALVOVA et al., 2003; WANG et al., 2004; DIAZ et al., 2007; RUBEL et al., 2010) once the Köppen climatic types is a great opportunity to show didactically for both specialists and general public how the climate zones are changing. In geography relationships between the distribution of population and the main climates in the world has been addressed (STASZEWSKI, 1963; KUMMU et al., 2011).

Rolim et al. (2007) have shown that the principles of climate classification are of great importance because they analyze and define the types of climates by altering consideration of several climatic factors at the same time, facilitating the exchange of information and analyzing for different objectives.

Andrade Júnior et al. (2005) stated that the climatic classification tends to identify a large area or region and zones with relatively homogeneous climatic andbiogeographic characteristics providing indications about the ecological conditions, their agricultural potential and the environment of the studied area.

The classification method of Köppen is the most used in Brazil, due to the approach with several agricultural crops and due to the lower stiffness of the formula for determining wet or dry month. In addition, the method was adapted to some differentiated situations in South America according to the authors Knoch et al (1930) and Barros et al. (2012). Still in 
accordance with Barros et al. (2012), the classification of Köppen is one of the most used systems in the science of geography, climatology and ecology. The classification is based on the hypothesis, originated in phytosociology and ecology, in which the natural vegetation of each region of the universe is essentially linked to a type of climate. The climatic regions are characterized to correspond to the areas of predominance of each type of vegetation. However, this classification in certain cases does not distinguish regions with distinct biomes (Köppen and Geiger, 1928).

Average air temperature and rainfall are important along climatic processes and are the subject of research related to agriculture. These meteorological elements exert a direct influence on the agricultural conditions according to Amorim et al. (2004).

Mazon et al, (2017) statesthat it's important to point out that the Köppen classification is based only on average values of air temperature and precipitation. Although climatologists and meteorologists analysing historical weather are able to reconstruct weather conditions of the past (Pino et al., 2016), often they limit their analysis of weather diversity to the use of these variables, first because air temperature and precipitation records are the most common and, second, because it is easy to measure variables by means of both the large network of automatic weather stations as well as the historical meteorological database.

Barros et al. (2012) emphasized that for the development of the climatic classification, it is restricted to indefinites of different genera due to the complexity of grouping factors related to the environment and/or simply mathematical indexes. Any classification of natural phenomena cannot fit into the systematic of the elements. However, several other acclimatic elements exert influence on the character of the vegetation, orography and soil implying the human activities in agriculture and vegetal exploration.

According to Mazon et al, (2017) the criteria developed by Köppen for the climatic classification has been used by several authors with different purposes: to study climatic variation, to evaluate the influence of climate change, to validate Global Circulation Models and to analyse scenario runs on spatio-temporal variations of climate, to compare with observational datasets and to assess the sensitivity of climate types to long-term climate change among other studies.

The Köppen Climate Classification is based on abundance and distribution of rainfall indices and annual/monthly temperature variability. The temperature and precipitation data are the initial criteria for the division of climate types. According to Köppen, in recent decades, adaptations of other authors have occurred, such as Setzer (1966), which simplified 
the classificatory keys.Setzer (1966) states that in the distribution of pluviometric stations with spatialization adjusted by the Köppen method there is an excellent distribution of climatic types in the regions of the State.

For Almorox et al (2015), most applications of the Köppen system are concerned with mapping the geographic distribution of the world's climate or vegetation with the help of a long term climate dataset. Depending on the data used, the mappings may have different details and qualities for such a stationary description of the world's climate.

The objective of this article is to perform the climatic classification using the model of the Köppen application for the State of Pernambuco with the elaboration of a map.

\section{MATERIAL AND METHODS}

The State of Pernambuco is located in the center-east of the Northeast of Brazil (NEB) and limits to the north with the state of Paraíba, to the northwest it borders with the state of Ceará, in the southeast position with the states of Alagoas and Bahia (in the South) and with Piauí to the west, besides being bathed by the Atlantic Ocean in the east sector. It occupies an area of $98.937 .8 \mathrm{~km}^{2}$. The archipelagos of Fernando de Noronha, São Pedro and São Paulo are part of its territory.

Being one of the smallest states of Brazil in territorial extension, Pernambuco has great diversity of landscapes: plateaus, mountains, swamps, semiarid and beautiful beaches. The most regular relief is in the coastal plain and as it moves to the interior of the state, there are peaks of mountains surpassing the 1,000 meters of altitude.

The vegetation cover is much diversified, with forests, mangroves and savannahs, besides a strong presence of caatinga. The coastal vegetation predominates in areas near the ocean, being found many coconut trees, mangroves and in some cases, shrubs. The tropical forest is where there was originally Mata Atlântica. There were few remnants of this important Brazilian forest. Finally, in the agreste and in the backlands of Pernambuco, what predominates is the vegetation of the caatinga. As for hydrography, there are many rivers, mainly in the Metropolitan Region of Recife (the capital of the state of Pernambuco), which has 14 municipalities. The main rivers of the state are Capibaribe and Beberibe, Ipojuca, Una, Pajeú, Jaboatão and São Francisco, this last one being extremely important in the development of the backlands, since it allows the distribution of water to the regions affected by drought. 
The rainfall or rainfall systems for the state of Pernambuco that contribute moderate to weak rainfall indexes are the vestiges of frontal systems in the southern sector of the state at a lower frequency, due to the contributions of the South Atlantic Convergence Zones (SACZ), besides the formations of the convective agglomerates, and the contribution of the Alta of Bolivia. The Intercontinental Conversity Zone (ZCIT), a disturbance associated with the expansion to the southern hemisphere of the thermal equator (the heat rise zone of the trade winds by thermal convection) causes moderate to strong rains in almost all of the northern part of the State.

The contributions of the Formations of the High Level Cyclic Vortices (VCAN), the Eastern Undulating Disturbances, the Sea and Land Breezes, this last one originating in the Atlantic Ocean; East waves are common in the autumn and in thewinter, aided by south-east trade winds (Figure 1).

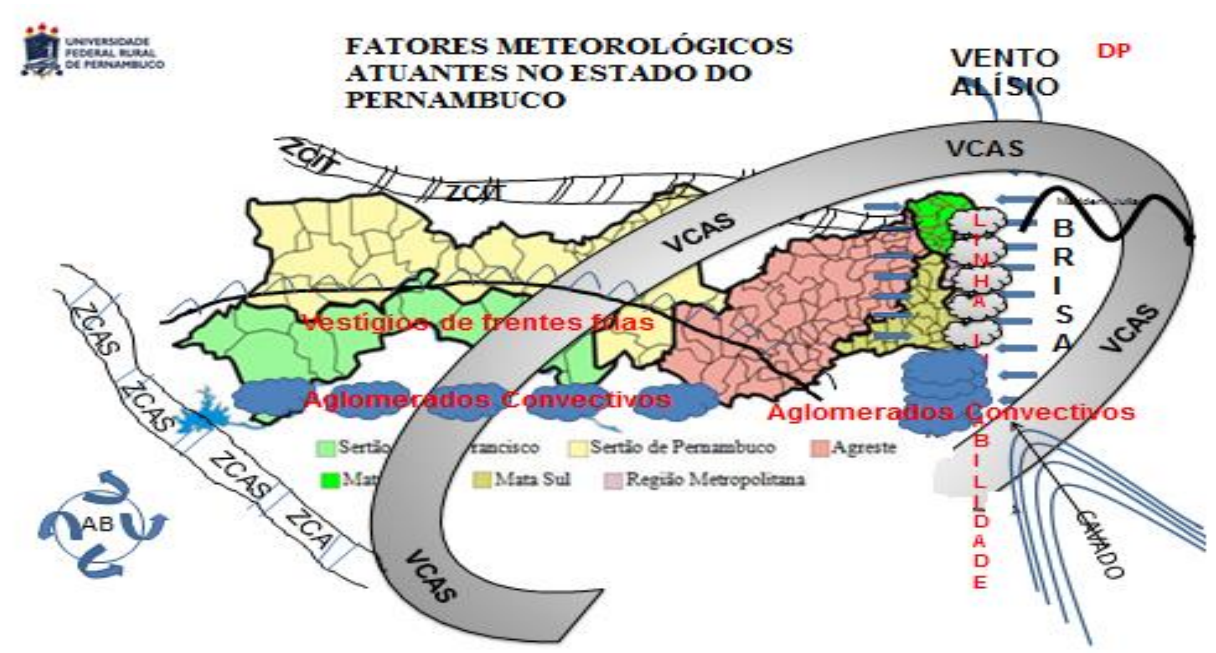

Figure 1.Illustrations of the meteorological factors in the state of Pernambuco. Source: Adapted by Medeiros (2016).

The values of the mean air temperature of the last 50 years estimated by the software Estima_T (Cavalcanti and Silva, 1994; Cavalcanti et al., 2006) were used. Estima_T is a software for estimating air temperatures in the Northeast Region of Brazil. This region was divided into three areas: area 1 comprising the states of Maranhão and Piauí; area 2 specific for the states of Ceará, Rio Grande do Norte, Paraíba and Pernambuco, and area 3 for the states of Alagoas, Sergipe and Bahia. For all regions (1,2 and 3), the coefficients of the quadratic function for the mean, maximum and minimum monthly temperatures were determined according to the local coordinates: longitude, latitude and altitude in accordance with the authors Cavalcanti and Silva (2006) and are given by: 


$$
\mathrm{T}=\mathrm{C}_{0}+\mathrm{C}_{1} \lambda+\mathrm{C}_{2} \varnothing+\mathrm{C}_{3} \mathrm{~h}+\mathrm{C}_{4} \lambda^{2}+\mathrm{C}_{5} \varnothing^{2}+\mathrm{C}_{6} \mathrm{~h}^{2}+\mathrm{C}_{7} \lambda \varnothing+\mathrm{C}_{8} \lambda \mathrm{h}+\mathrm{C}_{9} \varnothing \mathrm{h}
$$

Which:

$\mathrm{C}_{0}, \mathrm{C}_{1}, \ldots, \mathrm{C}_{9}$ are the constants;

$\lambda, \lambda_{2}, \lambda \varnothing, \lambda \mathrm{h}$ longitude;

$\varnothing, \varnothing_{2}, \lambda \varnothing$ latitude;

$\mathrm{h}, \mathrm{h}_{2}, \lambda \mathrm{h}, \varnothing \mathrm{h}$ height.

It was estimated the time series of temperature, adding it to the temperature anomaly of the Tropical Atlantic Ocean (Silva et al., 2006).

$$
\mathrm{T}_{\mathrm{ij}}=\mathrm{T}_{\mathrm{i}}+\mathrm{AAT}_{\mathrm{ij}} \mathrm{i}=1,2,3, \ldots, 12 \quad \mathrm{j}=1950,1951,1952, \ldots .2015
$$

Which:

$\mathrm{I}=1,2,3, \ldots, 12$

$\mathrm{J}=1950,1951,1952,1953, \ldots, 2015$.

Electronic spreadsheets were prepared with the monthly and annual data of historical temperature and precipitation, with the completions of failures followed by their consistencies. "Surfer 10" software was applied to the statistics using the Kriging process, making the mentioned monthly and annual maps.

Rainfall data were collected by the Northeast Development Superintendency (SUDENE) and the Pernambuco Water and Climate Agency (APAC). The pluviometric stations studied had thirty or more years of observations in accordance with the standards of the World Meteorological Organization (WMO).

In this article it was not possible to make the series of precipitations in a standardized method for the 30 years due to the difference in the beginning of the operation between the mentioned pluviometric stations. The climatic classification was performed using the Köppen-Geiger methodology according to the descriptions below.

\section{Köppen climate classification method}


The climate of a region results from the different combinations of atmospheric processes with a diversity of typologies.

Climate regions are the combined effects of factors that result in a set of approximately homogeneous atmospheric conditions. In order to map the Climate Regions, it is necessary to identify and classify each type:

The Classification has three objectives:

1 - Organize large amounts of information;

2 - Retrieve information quickly;

3 - Facilitate communication.

The objective of this classification is to define in terms of temperature, humidity and seasonal distributions the limits of the different climatic types that occur on the surface of the globe and especially in the State of Pernambuco.

The classification of Köppen is based on the amount and distribution of annual precipitation, annual and monthly temperatures.

\section{Climate category}

There are five major climate categories that have been listed with uppercase designations: A, B, C, D, E.

For the specific study of tropical region, categories A, B and C will be addressed; Types $\mathrm{A}$ and $\mathrm{C}$ are considered wet and type $\mathrm{B}$ is dry.

\section{Dry-dry climate division}

The division between humid and dry climate is done through the following formulas: a) If the precipitation is uniform in every month, that is, if there is a good distribution of precipitation throughout the year, without concentration in the winter nor the summer, the formula used is:

$$
r=20 t+140
$$

where:

$\mathrm{r}$ - Theoretical value of annual precipitation $(\mathrm{mm})$; 
$\mathrm{t}$ - Annual average temperature $\left({ }^{\circ} \mathrm{C}\right)$.

b) If the concentration of precipitation is in the summer, that is, if $70 \%$ or more of the annual precipitation occurs in the months of April to September in the Northern Hemisphere (HN) and October to March in the HS, the following formula is used:

$$
r=20 t+250
$$

c) If the concentration of precipitation occurs in the winter, that is, $70 \%$ or more of the annual precipitation is from October to March in the $\mathrm{HN}$ and from April to September in the Southern Hemisphere (HS), the following formula is used:

$$
\mathrm{r}=20 \mathrm{t}
$$

With these values, it is possible to determine if the climate is humid or dry.

Prp - Annual average rainfall (mm), (70\%);

$\operatorname{Prp}>\mathrm{r} \rightarrow$ moist climate (A or C);

$\operatorname{Prp}<\mathrm{r} \rightarrow$ dry climate $(\mathrm{B})$

According to the above comparison, one has a definition whether the climate is dry or humid.

From there, the next step is to define the type of climate. According to the ratings.

A - Tropical humid ( Megathermal) - average temperature of the coldest month above $18{ }^{\circ} \mathrm{C}$;

B - Desert or steppe - without temperature limit;

$\mathrm{C}$ - Temperate (Mesothermic). Average temperature of the coldest month between $-3{ }^{\circ} \mathrm{C}$ and $18{ }^{\circ} \mathrm{C}$.

In these types of climate, there are subtypes found in the tropical region (mountainous region).

Capital letters refer to temperature and lowercase letters to precipitation, except for type B, where lowercase letters refer to temperature.

\section{Climate of type a - subcategories}

Af - Moist. Rainforest Climate. The dry month has mean precipitation $\geq 60 \mathrm{~mm}$.

Medeiros, Holanda, Viana, Silva, $2018 \quad$ ISSN 0104-5490 226


Am - Moist.Forest weather. Dryer month with mean rainfall less than $60 \mathrm{~mm}$ and total annual rainfall greater than 10 times this value.

Aw - Humid with dry winter. Climate of Savana. Dryer month with average rainfall less than $60 \mathrm{~mm}$ and total annual rainfall less than 10 times this value.

To facilitate the definition of the climatic subcategory, the following criteria are used:

1 - "Af" never has rainfall less than $60 \mathrm{~mm}$, that is, there is no dry season.

2 - To define "Am" and "Aw", the following analysis is used:

\begin{tabular}{ll}
\hline $\mathrm{P}>10 \mathrm{p}$ & Tipo Am \\
$\mathrm{P}<10 \mathrm{P}$ & Tipo Aw \\
\hline
\end{tabular}

where:

$\mathrm{P}$ - mean precipitation of the driest month $(\mathrm{mm})$. Theoreticalvalue;

$\mathrm{P}$ - total annual precipitation ( $\mathrm{mm})$.

Climate of type $b-$ subcategories

Bs - Dry or semi-arid. It is the transition from the humid climate to the desert;

Bw - Desert or arid.

The following criteria were used to define the subcategories:

1) If precipitation is evenly distributed during the year, the formula shall be:

\begin{tabular}{ll}
\hline $\begin{array}{l}P<t+7 \\
\mathrm{t}+7>\mathrm{P}>2 \mathrm{t}+14\end{array}$ Tipo $B s$ \\
\hline
\end{tabular}

Where:

$\mathrm{T}$ - average annual temperature in ${ }^{\circ} \mathrm{C}$;

$\mathrm{P}$ - mean annual total precipitation $(\mathrm{Cm})$.

2) If $70 \%$ or more of precipitation occurs in the summer

\begin{tabular}{cr}
\hline $\mathrm{P}<\mathrm{t}+14$ & Tipo Bw \\
$\mathrm{t}+14>\mathrm{P}>2 \mathrm{t}+2 i_{\text {Tipo Bs }}$ & \\
\hline
\end{tabular}

Where:

Medeiros, Holanda, Viana, Silva, 2018

ISSN 0104-5490 
$\mathrm{T}$ - average annual temperature in ${ }^{\circ} \mathrm{C}$;

$\mathrm{P}$ - mean annual total precipitation $(\mathrm{Cm})$.

3 ) If $70 \%$ or more of precipitation occurs in the winter

\begin{tabular}{cc}
\hline $\mathrm{P}<\mathrm{t}$ & Tipo $B w$ \\
$\mathrm{t}>\mathrm{P}>2 \mathrm{t}$ & \multicolumn{1}{c}{ Tipo $B \mathrm{~s}$} \\
\hline
\end{tabular}

Where:

$\mathrm{T}$ - average annual temperature in ${ }^{\circ} \mathrm{C}$;

$\mathrm{P}$ - mean annual total precipitation $(\mathrm{Cm})$.

Each of these subcategories is subordinated according to temperature, in the following types:

$\mathrm{K}$ - cold - average annual temperature below $18{ }^{\circ} \mathrm{C}$;

$\mathrm{H}$ - hot - average annual temperature above $18{ }^{\circ} \mathrm{C}$.

Type C Climate - subcategories

$\mathrm{Cw}$ - Winter dry (Tropical altitude). Rainfall is summer. This subcategory represents a climatic type that can occur in mountainous regions.

Maximum summer precipitation $\geq 10 \mathrm{p}$ (precipitation of the driest month).

Cs - Summer dry. Rain is winter.

Maximum winter precipitation $\geq 3 \mathrm{p}$ (driest month) with $\mathrm{p}<30 \mathrm{~mm}$.

Note: If $\mathrm{p}>30 \mathrm{~mm}$, we will have the particular case of Cfs, which is not summer dry, but only the driest season occurs in the summer.

Cf - Constantly Moist.

If the rain is Summer Prp maximum of summer $<10 p$ (precipitation of the driest month) If the rain is winter Prp maximum of winter $<3 p$ (precipitation of the driest month) Divisions of this subcategory $(\mathrm{C})$ :

Hottest Month Temperature $>22 \square \mathrm{C}$ a - Sub Tropical

Hottest month temperature $<22 \square \mathrm{C} \mathrm{b}$ - Temperate itself 


\section{RESULTS AND DISCUSSION}

Figure 2 shows the variability according to the climatic classification for the state of Pernambuco with the Köppen model. The most frequent occurrences are the As with the most predominant types, the BSh type with intermediate predominance and the Am climate (Humidity). Dryer month with mean precipitation less than $60 \mathrm{~mm}$ and Precipitation Total (annual value greater than 10 times this value) in smaller proportions (figure 2).

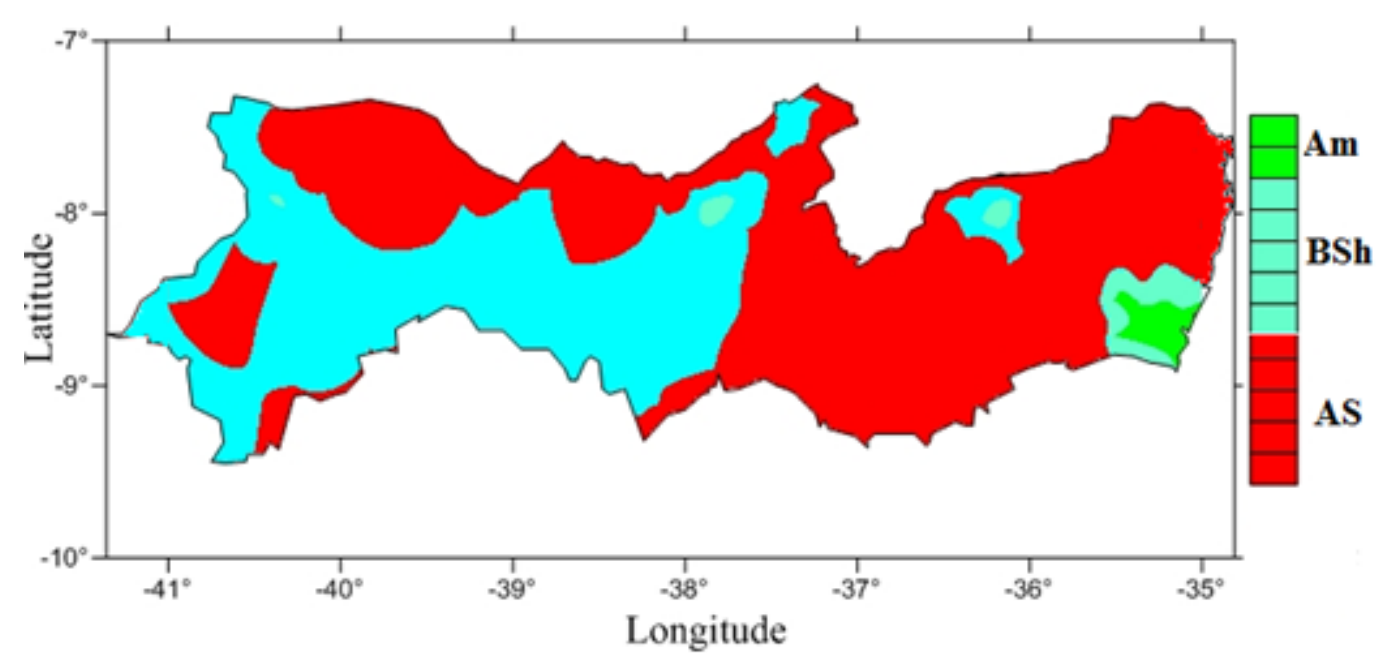

Figure 2.Climatic classification according to the Köppen model for the State of Pernambuco. Source: Medeiros (2016).

Similar results were found by Alvares et al. (2014) in the climatic classification for Brazil in which the coast of Northeastern Brazil, with climate Am, in the Coastal Tablelands of João Pessoa, extending to the coast of the State of Pernambuco, stands out.

Almorox et al. (2015), states that the Köppen climate classification was recently updated by Kottek et al. (2006) and Peel et al. (2007), and it is still the most widely adopted, since it uses natural vegetation as an expression of climate and the classification only depends on temperature and precipitation. This climate-vegetation association provides a relationship between a multivariate description of climate and an easily visualized landscape,this information corroborates with the study developed in this paper.

Table 1 shows the statistical oscillations of mean air temperature in the state of Pernambuco. The parameters studied refer to the variability of the mean minimum temperature, mean maximum and average mean, followed by its median, standard deviation and coefficient of variance representative of the 187 municipalities that compose the state formation. 
Table 1. Statistical oscillations for mean air temperature in the state of Pernambuco.

\begin{tabular}{lcccccc}
\hline Months & temperature & temperature & Standard Coefficient & Median deviation & Variance & Maximum Minimum \\
\hline Jan & 27.3 & 22.5 & 25.1 & 25.9 & 1.18 & 0.047 \\
Feb & 27.4 & 22.2 & 25.0 & 25.8 & 1.30 & 0.052 \\
Mar & 27.0 & 22.1 & 24.8 & 25.6 & 1.24 & 0.050 \\
Apr & 26.4 & 21.1 & 24.1 & 25.0 & 1.33 & 0.055 \\
Mai & 25.6 & 20.0 & 23.1 & 24.1 & 1.39 & 0.060 \\
Jun & 24.6 & 18.6 & 22.0 & 23.1 & 1.49 & 0.068 \\
Jul & 24.0 & 18.1 & 21.5 & 22.6 & 1.48 & 0.069 \\
Aug & 23.9 & 18.3 & 21.7 & 23.1 & 1.44 & 0.067 \\
Set & 24.8 & 20.0 & 22.9 & 24.3 & 1.25 & 0.055 \\
Out & 25.8 & 21.2 & 24.1 & 25.3 & 1.19 & 0.050 \\
Nov & 26.6 & 21.9 & 24.7 & 25.6 & 1.17 & 0.047 \\
Dec & 27.2 & 22.2 & 25.0 & 25.8 & 1.25 & 0.050 \\
Annual & 25.9 & 20.7 & 23.7 & 24.7 & 1.31 & 0.056 \\
\hline
\end{tabular}

The oscillation of the maximum average temperature flows between $23.9{ }^{\circ} \mathrm{C}$ in August and $27.4{ }^{\circ} \mathrm{C}$ in February with an annual rate of $25.9{ }^{\circ} \mathrm{C}$. The minimum average temperature variability occurs between $18.1{ }^{\circ} \mathrm{C}$ in July to $22.5{ }^{\circ} \mathrm{C}$ in January as well as $20.7{ }^{\circ} \mathrm{C}$ to its annual mean temperature. The average temperature of the annual averages is $23.7^{\circ} \mathrm{C}$ and its oscillations occur between $21.5^{\circ} \mathrm{C}$ and $25.1^{\circ} \mathrm{C}$. The fluctuation of the median occurs between $22.6{ }^{\circ} \mathrm{C}$ to $25.8^{\circ} \mathrm{C}$ with its annual value of $24.7{ }^{\circ} \mathrm{C}$. The standard deviation stands out in the months of June, July and August with high values and the month of November with reduced indexes. The coefficients of variance in general do not show significant fluctuations.

\section{CONCLUSIONS}

According to Köppen's classification systems, three climatic characteristics were identified: in relation to the AS climate type, in 108 municipalities, the hot semi-arid climate with summer and dry winter (BSH) was registered in 55 municipalities and the type Am climate predominated in 20 municipalities;

Rainfall regimes and temperature variations were determinant for the calculations and their spatial distribution;

The climatic classification according to Köppen for the studied area is in accordance with the Camargo (1961) classifications;

The Köppen climate classification system is efficient only for the macro-scale and with low capacity for separating climate types, taking into account air temperature, rainfall 
and elements resulting from the water balance. Consequently, it should not be used in regional agro-climatic studies as in the determination of Agro meteorological zones.

\section{ACKNOWLEDGEMENTS}

The Coordination of Improvement of Higher Level Personnel (CAPES) for the granting of a post doctoral fellowship and the Coordination of the Center for Environmental Engineering for research in development.

\section{REFERENCES}

ALMOROX, Javier; QUEJ, Victor H.; MARTÍ, Pau. Global performance ranking of temperature-based approaches for evapotranspiration estimation considering Köppen climate classes. J Hydrol, v. 528, p. 514-522, 2015.

ALVARES, Clayton Alcarde et al. Köppen's climate classification map for Brazil. Meteorol. Z., v. 22, n. 6, p. 711-728, 2013.

AMORIM, R.C.F.; AMORIM, R.F.C.; AMORIM, D.K.F.; LEITE, C.C.; GOMES, H.B. Climatic analysis for the city of Curitiba / PR. In: Brazilian congress of Meteorology, 13, Fortaleza, 2004. Anais ... Fortaleza, 2004.

APARECIDO, Lucas Eduardo de Oliveira et al. Köppen, Thornthwaite and Camargo climate classifications for climatic zoning in the State of Paraná, Brazil. Ci. Agrotec., v. 40, n. 4, p. 405-417, 2016.

ARAÚJO, R.F.; MATRICARDI, E.A.T. ; NAPPO, M.E. Zoneamento ecológico de pequena escala para espécies florestais tradicionais no Distrito Federal. R. Fl., v. 42, n. 2, p. 421-430, 2012.

BARROS, Alexandre Hugo Cezar et al. Climatologia do Estado de Alagoas. Boletim de Pesquisa e Desenvolvimento (INFOTECA-E), n. 211. Recife: Embrapa Solos, p.32. 2012. 
CAVALCANTI, E.P.; SILVA, E.D.V. Estimation of air temperature as a function of local coordinates. VIII Brazilian Congress of Meteorology and II Latin American and Iberian Congress of Meteorology. Brazilian Society of Meteorology. Belo Horizonte, p. 154-157, 1994.

CAVALCANTI, E.P.; SILVA, V.P.R.; SOUSA, A.S. A computer program to estimate air temperature for Northeast region of Brazil. Rev. Bras. Eng. Agrí. Ambient. v. 10, n. 1, p. 140-147, 2006.

COSTA, T.S.A.; COSTA FILHO, J.F.; BARACHO, D.C.; SANTOS, T.S.; MARINHO, E.C. S. Analysis of air temperature in Sand - PB, in years of occurrence of "El Niño". Presented at the XVII Brazilian Congress of Agrometeorology - July 18 to 21, 2011 - SESC Guarapari Tourism Center, Guarapari - ES. 2011.

CHEN, Deliang; CHEN, Hans Weiteng. Using the Köppen classification to quantify climate variation and change: an example for 1901-2010. Environ Dev, v. 6, p. 69-79, 2013.

DIAZ, H.F.; EISCHEID, J.K. Disappearing "alpine tundra" Köppen climatic type in the western United States. Geophys Res Lett, v. 34, n. 18, 2007.

FRAEDRICH, K.; GERSTENGARBE, F.W.; WERNER, P.C. Climate shifts during the last century. Climatic Change, v. 50, n. 4, p. 405-417, 2001.

GNANDESIKAN, A.; STOUFFER, R.J. Diagnosing atmosphere-ocean general circulation model errors relevant to the terrestrial biosphere using the Köppen climate classification. Geophys Res Lett, v. 33, n. 22, 2006.

GONÇALVES, J.L.M. et al. Integrating genetic and silvicultural strategies to minimize abiotic and biotic constraints in Brazilian eucalypt plantations. Forest Ecol Manag, v. 301, p. 6-27, 2013. 
JÚNIOR, Aderson Soares de Andrade et al. Classificação climática e regionalização do semiárido do Estado do Piauí sob cenários pluviométricos distintos. Revista Ciência Agronômica, v. 36, n. 2, p. 143-151, 2005.

JURCA, Janaína. Classificações climáticas: variações temporo-espaciais e suas aplicações nos livros didáticos e como subsídio ao zoneamento agroclimático. 2005. 100 f. Dissertação (mestrado) - Universidade Estadual Paulista, Faculdade de Ciências e Tecnologia, Presidente Prudente, São Paulo, 2005.

KALVOVÁ, Jaroslava et al. Köppen climate types in observed and simulated climates. Stud Geophys Geod, v. 47, n. 1, p. 185-202, 2003.

KÖPPEN, W.; GEIGER, R. Klimate der Erde. Gotha: Verlagcondicionadas. Justus Perthes. n.p. 1928.

KOTTEK, Markus et al. World map of the Köppen-Geiger climate classification updated. Meteorol Z, v. 15, n. 3, p. 259-263, 2006.

KUMMU, M.; VARIS,O. The world by latitudes: The global analysis of human population, development level and environment across the north-south axis over the past half century. Appl Geogr, v. 31, n. 2, p. 495-507, 2011.

MAES, W. H. A. et al. Climatic growing conditions of Jatropha curcas L. Biomass and Bioenergy, v. 33, n. 10, p. 1481-1485, 2009.

MAZON, Jordi; PINO, David. Meteodiversity: a new concept for quantifying meteorological diversity. Weather, v. 72, n. 5, p. 143-145, 2017.

MCMAHON, Thomas A. et al. Global streamflows-Part 3: Country and climate zone characteristics. J Hydrol, v. 347, n. 3-4, p. 272-291, 2007.

OMETTO, J.C. Plant bioclimatology. São Paulo: Ed. Agronômica Ceres Ltda., 1981. 413p. 
PEEL, Murray C.; FINLAYSON, Brian L.; MCMAHON, Thomas A. Updated world map of the Köppen-Geiger climate classification. Hydrol Earth Syst Sci Discuss, v. 4, n. 2, p. 439473, 2007.

PINO, David et al. Meteorological and hydrological analysis of major floods in NE Iberian Peninsula. J Hydrol, v. 541, p. 63-89, 2016.

ROLIM, Glauco de Souza et al. Climatic classification of Köppen and Thornthwaite sistems and their applicability in the determination of agroclimatic zonning for the state of São Paulo, Brazil. Bragantia, v. 66, n. 4, p. 711-720, 2007.

RUBEL, Franz; KOTTEK, Markus. Observed and projected climate shifts 1901-2100 depicted by world maps of the Köppen-Geiger climate classification. Meteorol Z, v. 19, n. 2, p. 135-141, 2010.

SEREBRENICK, S. Mapa climatológico do Brasil. Ministério da Agricultura, Rio de Janeiro, 1941.

SETZER, J. Climatic and Ecological Atlas of the State of São Paulo. Interstate Commission of the Paraná-Uruguay Basin. São Paulo, Brazil, p. 61, 1966.

SILVA, Paulo Henrique Muller et al. Selecting for rust (Puccinia psidii) resistance in Eucalyptus grandis in São Paulo State, Brazil. Forest Ecol and Manag, v. 303, p. 91-97, 2013.

SILVA, Vicente de P. R. et al. Teleconnections between sea-surface temperature anomalies and air temperature in northeast Brazil. J Atmos Sol Terr Phys, v. 68, n. 7, p. 781-792, 2006.

WANG, Muyin; OVERLAND, James E. Detecting Arctic Climate Change Using Köppen Climate Classification. Climatic Change, v. 67, n. 1, p. 43-62, 2004. 